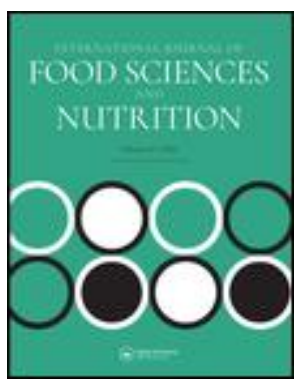

\title{
The effects of feeding supplementation on the nutritional quality of milk and cheese from sheep grazing on dry pasture
}

\begin{tabular}{|r|l|}
\hline Journal: & International Journal of Food Sciences and Nutrition \\
\hline Manuscript ID & Draft \\
\hline Manuscript Type: & Research Paper \\
\hline Author: & nubmitted by the \\
\hline Complete List of Authors: & $\begin{array}{l}\text { caprioli, giovanni; university of camerino, } \\
\text { Nzekoue, Franks; Universita degli Studi di Camerino } \\
\text { Fiorini, Dennis; University of Camerino } \\
\text { Scocco, Paola; Universita degli Studi di Camerino Scuola di Bioscienze e } \\
\text { Medicina Veterinaria } \\
\text { Trabalza Marinucci, Massimo; Universita degli Studi di Perugia } \\
\text { Dipartimento di Medicina } \\
\text { Acuti, Gabriele; Universita degli Studi di Perugia Dipartimento di } \\
\text { Medicina } \\
\text { Tardella, Federico; Universita degli Studi di Camerino Scuola di } \\
\text { Bioscienze e Medicina Veterinaria } \\
\text { Sagratini, Gianni; university of camerino, } \\
\text { Catorci, Andrea; Universita degli Studi di Camerino Scuola di Bioscienze } \\
\text { e Medicina Veterinaria }\end{array}$ \\
\hline Keywords: & $\begin{array}{l}\text { Feeding system, feed supplementation, sheep milk and cheese, Vitamins, } \\
\text { Fatty acids }\end{array}$ \\
\hline
\end{tabular}

\section{SCHOLARONE \\ Manuscripts}




\section{The effects of feeding supplementation on the nutritional quality of milk and cheese from sheep grazing on dry pasture}

Giovanni Capriolia, Franks Kamgang Nzekoue ${ }^{a}$, Dennis Fiorini ${ }^{b}$, Paola Scocco ${ }^{\mathrm{c}}$, Massimo

Trabalza-Marinucci ${ }^{\mathrm{d}}$, Gabriele Acutid ${ }^{\mathrm{d}}$, Federico M. Tardella ${ }^{\mathrm{c}}$, Gianni Sagratini ${ }^{\mathrm{a} *}$, Andrea Catorcic $^{\mathrm{c}}$

${ }^{a}$ School of Pharmacy, University of Camerino, Via Sant'Agostino 1, 62032 Camerino, Italy

${ }^{b}$ School of Science and Technology, Chemistry Division, University of Camerino, Via S. Agostino 1, 62032 Camerino, Italy

'School of Biosciences and Veterinary Medicine, University of Camerino, Via Pontoni 5, 62032 Camerino, Italy

${ }^{d}$ Department of Veterinary Medicine, University of Perugia, Via San Costanzo 4, 06126 Perugia, Italy

*Corresponding author: Gianni Sagratini, School of Pharmacy, University of Camerino, Via Sant' Agostino 1, 62032 Camerino, Italy. Phone: +390737402238. Fax: +390737637345. E-mail: gianni.sagratini@unicam.it 


\begin{abstract}
The effect of feeding supplementation on the nutritional characteristics of milk and cheese was studied in dairy sheep grazing on low mountain dry-grasslands during summer in typical sub-Mediterranean conditions of aridity. The control group (CG) sheep grazed on grass in these pastures, while the experimental group (EG) grazed on grass and received $600 \mathrm{~g}$ a day of a barley and corn mixture. Daily milk production showed a less pronounced decrease in EG than in CG ( $p$ two-tail test 0.0368). At the end of the study, the concentrations of retinol and $\alpha$-tocopherol in milk and cheese from EG were higher than CG $(p<0.05)$. Supplementary feeding had a positive effect on the fatty acid composition of the sheep milk. For the first time, positive effects on the volatile composition were found in EG cheese, displaying a lower percentages of carboxylic acids associated with the pungent and rancid odor with respect to $\mathrm{CG}$.
\end{abstract}

\title{
Keywords
}

Feeding system; feed supplementation; sheep milk and cheese; vitamins; fatty acids

\author{
Abbreviations \\ SFA Saturated fatty acid, MUFA monounsaturated fatty acid, PUFA polyunsaturated fatty \\ acid, CLA conjugated linoleic acid, FA fatty acid, SPME Solid phase micro-extraction.

\section{Chemical compounds studied in this article} \\ Retinol (PubChem: CID 445354), $\alpha$-tocopherol (PubChem: CID 14985)
}




\section{Introduction}

Sheep milk products can provide a profitable alternative to those from cows because of their specific taste, texture, typicity and the perception of these foods as natural and healthy. In this context, there is increased consumer interest in the nutritional composition of these products. Some major reviews have examined the biochemical composition of goat and sheep milk, which can be influenced by factors such as genetics, feeding, environment and technology (Raynal-Ljutova et al. 2008), as well as reasons for variations in composition (Jenness 1980; Remeuf et al. 1991), but little information is available on the specific molecules with nutritional properties, such as vitamins, and their variability. The importance of sheep milk to human health, its characteristics and its role in some populations have been widely demonstrated (Rubino et al. 1999; Boyazoglu and MorandFehr 2001; Morand-Fehr et al. 2007). In arid and poor areas where it is difficult to raise cattle and the population is at risk of malnutrition, sheep milk is a sustainable source of high quality protein and calcium. In general, consumers often consider sheep-rearing to be more ecological than cattle-rearing, and also view their products a priori as more healthy than others. The composition in macro- and micro- nutrients of milk and cheese depends on the main production factors of the farming system: genotype, reproduction, agroclimatic conditions, and farming methods such as milking and feeding (Morand-Fehr et al. 2007). The literature offers abundant information on the factors influencing the composition of cow milk, the most important of which appears to be feeding (Agabriel et al. 1995; Agabriel et al. 2001; Morand-Fehr et al. 2007) as it is the factor the masters easily chose and whose results can be quickly appreciated. One feeding study compared the fat content of goat milk from animals kept outdoors and nourished exclusively by grazing, and that of animals kept indoors and provided a concentrate supply: the fat content in milk from the outdoor group was lower than that of the indoor group (2.99\% vs $2.77 \%$ ) (Min et 
al. 2005). However, in an earlier study, the opposite was found to be the case $(2.9 \%$ vs $3.1 \%$ and $4.05 \%$ vs $4.52 \%$ ) (Pizzoferrato et al. 2000). In sheep, the fat content of milk from ewes that live and are fed indoors with hay, silage and concentrate (7.24\%) is usually higher than that from ewes that graze/spend their days outdoors, grazing on open pasture (6.98\%) (Pirisi et al. 2001). Feeding studies have also focused on the protein content in milk. Protein content in milk is more stable than fat content and it is less influenced by changes in feeding than is fat content and this is true also for lactose (Morand-Fehr et al. 2007). A feeding study on goats reported that the contents in $\alpha$-tocopherol and retinol (Vitamin A) are higher (often significantly) in milk from goats reared on pasture system than those kept indoors, a result often reported also for cows (Coulon et al. 2003). This situation holds even when concentrate feed is distributed ad libitum in addition to a pasture diet (Pizzoferrato et al. 2000). Unfortunately, similar information for sheep is lacking. A feeding study focused on fatty acids reported that milk from goats reared on pasture had higher contents in C18 fatty acids, particularly polyunsaturated fatty acids (Sanz Sampelayo et al. 2007), and noted that this composition was highly influenced by the ingested feeds. Summarising, the main components of goat and sheep milk appear to be less influenced by the type of farming system (indoors vs outdoors) than by the feeding system (pasture alone vs pasture plus feed supplements) (Morand-Fehr et al. 2007).

For cheese, less information is available in the literature, and the task is more complicated because of the variability in milk composition itself and in the cheese making process.

Stakeholders in semi-extensive farming systems in the Mediterranean mountain ranges are concerned about forecasts of increased aridity due to climate changes (Giorgi and Lionello 2008), as it worsens the forage feed value and lessens the availability of aboveground phytomass, thus making these farming system less sustainable (Nardone et al. 2010; Scocco et al. 2016a). Moreover, these changes also cause modifications in the normal life 
cycle of pastures, reducing the length of the time between pasture maximum flowering and maximum dryness, which means that high quality pasture is available to animals for less time, and thus that the well-being of the animals deteriorates (Scocco et al. 2013; Scocco et al. 2016b), which in turn can affect the quantity and quality of milk and milk products. Because of this, testing breeding system to face climate change is a key goal, especially where food quality is a core value in promotion of agricultural products, as is the case of Italian Apennine mountain farming systems.

Thus, the aim of this work was to assess the influence of feeding on the nutritional value, fatty acid composition, retinol and $\alpha$-tocopherol content of milk and cheese from sheep reared on pasture (control group, CG) and those reared on pasture plus supplementary feeding (experimental group, EG).

\section{Materials and methods}

\section{Animals, diets and experimental procedures}

The experiment was performed near the Natural Reserve of "Montagna di Torricchio" from July 8 to August 9, 2016, in the period between the maximum flowering and the maximum dryness of the pasture. After the pasture flowering peak, when the feed value of the grassland is at its maximum (Scocco et al. 2016a), fifty pluriparous Comisana ewes at late lactation were divided in two groups ( 25 ewes each) balanced for milk yield and body condition score (Russel et al. 1969) to guarantee the normal social behaviour of animal. All ewes were housed from 7:00 $\mathrm{pm}$ to 8:00 am and had unlimited access to pasture for the rest of the day. The control group (CG) fed on grass pasture ad libitum while the experimental group (EG) fed on grass pasture ad libitum and then received $600 \mathrm{~g} /$ day/head of equal parts of barley and corn in two equal portions before and after pasture. Food supplementation (performed according to the management habits of the farmer) represents an easy and less expensive farmer management action that could be able to buffer the negative effects of 
drought stress on the animal productivity. This type of supplementation was chosen according to the farmer, because it is usually adopted when there are some problems in the animal feed, so it doesn't represent an additional management weigh. The chemical composition of this supplement is reported in Table 1S (Supplementary Materials). Feed supplements is mainly constituted by starch (57\%), protein $(10 \%)$, crude fibre $(3.7 \%)$, fat (3\%) and free sugars (2.1\%) (Mercati et al. 2018). It contains also retinol, $\alpha$-tocopherol and fatty acids (Table 1S). Animals had access to water twice a day, morning and evening. All husbandry and experimental procedures were approved by the institutional ethics committee and the Italian Ministry of Health (No. of approval 95/2018-PR).

\section{Chemicals and reagents}

Retinol $\left(\mathrm{C}_{20} \mathrm{H}_{30} \mathrm{O}\right.$, molecular weight 286.46 , 95\% minimum, CAS No. 68-26-8) and $\alpha-$ tocopherol $\left(\mathrm{C}_{29} \mathrm{H}_{50} \mathrm{O}_{2}\right.$, molecular weight 430.72, $>96 \%$ HPLC, CAS No. 10191-41-0) were supplied by Sigma-Aldrich (Milano, Italy). Individual stock solutions were prepared by dissolving $10 \mathrm{mg}$ of pure standard in $10 \mathrm{ml}$ acetonitrile. HPLC-grade methanol, ethanol, $i$ propanol, acetonitrile, $n$-hexane, chloroform and ethyl acetate were supplied by SigmaAldrich (Milano, Italy), while deionized water ( $>18 \mathrm{M} \Omega \mathrm{cm}$ resistivity) was obtained from the Milli-Q SP Reagent Water System (Millipore, Bedford, MA, USA). All the solvents and solutions were filtered through a $0.45-\mu \mathrm{m}$ PTFE filter from Supelco (Bellefonte, PA, USA) before use. Potassium hydroxide, and sodium chloride analytical reagents were purchased from PROLABO VWR (Milano, Italy). L-(+)-Ascorbic acid 99\% and anhydrous sodium sulphate were purchased from Sigma-Aldrich (Milano, Italy). The solid-phase microextraction (SPME) fiber assembly used (Supelco, Bellefonte, PA) was Divinylbenzene/Carboxen/Polydimethylsiloxane (DVB/CAR/PDMS) 50/30 $\mu \mathrm{m}$.

\section{Nutritional composition of milk and cheese}


Ewes were machine-milked twice daily and milk samples were individually collected from all the animals from each group on July 8, 13, 21, 27 and August 9, 2016 in order to analyze the chemical composition (casein, fat, lactose, protein and urea) using a MilkoScan 6000 (Foss Electric, Hillerød, Denmark; Biggs, 1978) and the somatic cells/mL (Fossomatic 5000; Foss Electric, Hillerød, Denmark). Milk yield was recorded for each ewe, and the total amount of milk produced by the two groups at the morning milking was noted. A traditional cheese-making technique was used to make Pecorino cheese from bulk milk samples collected from the two groups at the beginning and at the end of the experimental period. Raw milk from each group were collected and were heated to $37{ }^{\circ} \mathrm{C}$, and calf rennet was added to curdle the milk. After the milk had clotted, the curd was cut to the size of little maize grains. The curd was cooked at $42{ }^{\circ} \mathrm{C}$ for $5 \mathrm{~min}$ and, after being removed from the vat, was pressed into $14 \mathrm{~cm}$ diameter perforated cylindrical moulds in order to drain the whey. Cheeses were treated with dry fine salt for $24 \mathrm{~h}$ and then transferred to a conditioned ripening room where they remained at a temperature of $12 \pm 1$ ${ }^{\circ} \mathrm{C}$ and a relative humidity of $80-85 \%$ for 30 days. 6 cheeses samples were obtained per process in each group and were analysed for moisture content by the AOAC (2000) method 934.01 and for ash content using the muffle furnace method 935.42 (AOAC, 2000). The fat content of cheese samples was determined by the Mojonnier method 995.19 (AOAC, 2000) and the total nitrogen was determined by the Kjeldahl method 991.20 (AOAC, 2000) while protein content was obtained by multiplying total $\mathrm{N}$ by a factor of 6.38 .

\section{Retinol and $\alpha$-tocopherol extraction and analyses in milk and cheese by HPLC-DAD}

Samples were extracted following a slightly modified method, (Fávaro et al. 2003). One ml of a solution of $\mathrm{NaCl} 1 \%(\mathrm{w} / \mathrm{v}), 0.05 \mathrm{~g}$ of ascorbic acid, $9 \mathrm{ml}$ of ethanol, $2 \mathrm{ml}$ of a $\mathrm{KOH}$ solution (10 $\mathrm{g} \mathrm{KOH}$ in $10 \mathrm{ml}$ water) and $3 \mathrm{ml}$ of sheep milk (or in the case of cheese, $3 \mathrm{~g}$ ) 
were placed in a tapered tube. In order to obtain a better dispersion of the homogenate, 4-6 $\mathrm{ml}$ of $\mathrm{NaCl} 1 \%$ were added. Alkaline digestion was performed in a water bath at $65{ }^{\circ} \mathrm{C}$ for 45 min with stirring (90 min for cheese samples). Tubes were cooled in an ice bath and 15 $\mathrm{ml}$ of $\mathrm{NaCl} 1 \%$ were added. Vitamin $\mathrm{A}$ and $\alpha$-tocopherol were extracted with three $6 \mathrm{ml}$ portions each ( $9 \mathrm{ml}$ for cheese) of hexane. The organic phase was evaporated under nitrogen and the residues dissolved in $1 \mathrm{ml}$ of acetonitrile. The volume of the supernatant was recorded and an aliquot was filtered through a $0.45 \mu \mathrm{m}$ PTFE membrane filter and injected into an HPLC-DAD system. HPLC-DAD studies were performed using an Agilent 1100 series (Santa Clara, CA, USA), made of an autosampler, a quaternary solvent pump, with a diode-array detector (DAD). The separation was achieved on a Chromolith RP-18e analytical column (100 x 3 mm I.D., macropore size $2 \mu \mathrm{m}$, mesopore size $13 \mathrm{~nm})$ from Merck (Darmstadt, Germany). The mobile phase for HPLC-DAD was: (A) acetonitrile $90 \%$ (B) $i$-propanol $10 \%$, flowing at $0.8 \mathrm{ml} \mathrm{min}^{-1}$ in isocratic conditions for a total run time of only 3 minutes. The column temperature was set at $40^{\circ} \mathrm{C}$ and the injection volume was $50 \mu \mathrm{L}$. HPLC/DAD analyses were performed monitoring the wavelength of $292 \mathrm{~nm}$ for $\alpha$ tocopherol and $326 \mathrm{~nm}$ for retinol.

\section{Determination of fatty acids composition in milk and cheese samples by gas}

\section{chromatography coupled with flame ionization detection (GC-FID)}

Eight $\mathrm{ml}$ of chloroform-methanol 2:1 (v/v) were added to an aliquot of $2 \mathrm{ml}$ of milk and the mixture was mechanically shaken for $10 \mathrm{~min}$. After centrifugation, the lower phase was collected and then $8 \mathrm{ml}$ of chloroform-methanol 2:1 (v/v) was added and the same procedure was repeated. The organic phase was washed with $3 \mathrm{ml} 0.73 \% \mathrm{w} / \mathrm{v} \mathrm{NaCl}$ aqueous solution. Afterwards, the organic phase was siphoned, dried over anhydrous sodium sulfate anhydrous, filtered, and dried under reduced pressure with a rotary evaporator. The lipid extract was weighted and aliquot subjected to transmethylation. 
Ninety $\mathrm{ml}$ of chloroform-methanol 2:1 (v/v) were added to $5 \mathrm{~g}$ of ground cheese in a 250 $\mathrm{ml}$ beaker and the mixture was extracted by a homogenizer (Ultra-Turrax, IKA, Germany) for $2 \mathrm{~min}$ and then transferred to a separatory funnel by washing the beaker walls with a total of $10 \mathrm{ml}$ solvent mixture. Twenty $\mathrm{ml}$ of saturated sodium chloride aqueous solution were added; the two phases of the system were shaken and the organic phase was collected and dried over anhydrous sodium sulphate, then filtered and stored at $-20^{\circ} \mathrm{C}$ before the analysis.

Transmethylation following Ichihara's procedure (Ichihara et al. 1996) was performed on each lipid extract. Briefly, a quantity of approximately $5 \mathrm{mg}$ of lipid extract, dissolved in 1 $\mathrm{ml}$ hexane, was added to $0.1 \mathrm{ml}$ of $2 \mathrm{M}$ methanolic $\mathrm{KOH}$ and vortexed for $2 \mathrm{~min}$. Then, 1.5 $\mathrm{ml}$ of $0.15 \mathrm{M}$ aqueous acetic acid were added and the solution was vortexed for $1 \mathrm{~min}$ and centrifuged at $5000 \mathrm{rpm}$ for $10 \mathrm{~min}$. The upper phase was transferred while $1 \mathrm{ml}$ hexane was added to the remaining one, which was then vigorously shaken and centrifuged at $5000 \mathrm{rpm}$ for $5 \mathrm{~min}$. This operation was repeated three times. Traces of water in the total hexane phase were removed with anhydrous sodium sulphate. Finally, the hexane solution containing fatty acid methyl esters (FAMEs) was sealed and stored at $-20^{\circ} \mathrm{C}$. Before the analysis, FAME solutions were evaporated to dryness with a nitrogen stream, dissolved in $1 \mathrm{ml}$ of hexane and analysed in duplicate. The gas chromatograph used was an Agilent Technologies 6850 equipped with a flame ionization detector (FID). The capillary chromatographic column was a DB-225 Agilent Technologies (length $30 \mathrm{~m}$, ID, $0.32 \mathrm{~mm}$; film thickness, $0.25 \mathrm{~mm}$ ) and the injected volume was $1 \mu$. The split ratio was 1:30 and the injector temperature was $260{ }^{\circ} \mathrm{C}$. The carrier gas was $\mathrm{H}_{2}$ and its initial flow was $3.7 \mathrm{ml}$ $\min ^{-1}$ in the column. High purity hydrogen was produced by a generator (PGH2-250 from DBS Analytical Instruments, Vigonza, Italy). The oven temperature was programmed to hold at $60{ }^{\circ} \mathrm{C}$ for $3 \mathrm{~min}$, then increase to $220{ }^{\circ} \mathrm{C}$ at $20^{\circ} \mathrm{C} / \mathrm{min}$, and hold at $220{ }^{\circ} \mathrm{C}$ for 8 
min. The FID detector temperature was $260{ }^{\circ} \mathrm{C}$ (air flow $400.0 \mathrm{ml} \mathrm{min}^{-1}, \mathrm{H}_{2}$ flow $40.0 \mathrm{ml}$ $\left.\min ^{-1}\right)$. Each analysis took 19 min. Identifications were done by analysing the standards (Supelco 37 Component FAME Mix) and conjugated linoleic acid methyl esters purchased from Supelco (Bellefonte, PA, USA) and Sigma-Aldrich (Milan, Italy), by GC-mass spectrometry (MS).

\section{Analysis of volatile fraction by SPME-GC-MS}

One gram of cheese was placed in a 10-ml vial and the sample was stirred for 20 min at 50 ${ }^{\circ} \mathrm{C}$ to accelerate equilibrium of headspace volatile compounds between the cheese matrix and the headspace. Then, extraction of volatile compounds was carried out by injecting a 50/30 $\mu \mathrm{m}$ divinylbenzene/carboxen/polydimethylsiloxane SPME fibre (Supelco, Bellefonte, PA) into the vial and exposing it to the headspace for $20 \mathrm{~min}$ at $50{ }^{\circ} \mathrm{C}$. After extraction, samples were directly desorbed into the injection port of the GC which was at $260{ }^{\circ} \mathrm{C}$. A gas chromatograph equipped with mass selective detector (GC-MSD) (Agilent, Santa Clara, CA; Agilent 6890N with Agilent 5973N) was used. Separation was performed on an DB-WAX MS column (60 m, 0.25mm i.d., $0.25 \mu \mathrm{m}$ film thickness). An Agilent Chem workstation was used with the GC-MS system. The flow rate (He) was $1 \mathrm{ml} \mathrm{min}{ }^{-1}$ under splitless mode. The injector temperature was $260{ }^{\circ} \mathrm{C}$. The column temperature program was from $35^{\circ} \mathrm{C}(4 \mathrm{~min})$ to $120{ }^{\circ} \mathrm{C}$ at $2.5^{\circ} \mathrm{C} \mathrm{min}-1$, then from $120^{\circ} \mathrm{C}$ to $250{ }^{\circ} \mathrm{C}$ at $15^{\circ} \mathrm{C} \mathrm{m^{-1 }}$. Total run time was 50 min. Data were acquired in the electron impact (EI) mode with an ionization voltage of $70 \mathrm{eV}$, using scan ion monitoring (SCAN mode). Data were analysed by using MSD Chem Station software (Agilent, Version G1701DA D.01.00). The results from the HS-SPMEGC-MS analysis of volatile components extracted by the SPME fibre were expressed as percentages, obtained by dividing the area of each component by the total area of all isolated components under the conditions described above. $n$-Alkanes (Sigma R-8769) were analysed under the same conditions to calculate 
retention indices $(\mathrm{RI})$ for the volatile compounds. The compounds were identified by three comparisons: with commercial reference compounds provided by Sigma-Aldrich (St. Louis, MO); by comparing their RI with those described in the literature; and their mass spectra with those contained in the NIST08 and WILEY 275 libraries.

\section{Statistical elaborations}

Linear models were performed using the $I m$ function (stats R-package, version 3.4.1; R Foundation for Statistical Computing, Vienna, Austria http://www.R-project.org) to assess the effect of treatment (categorical variable) and observation time during the experimentation (ordered factor), on retinol and $\alpha$-tocopherol, also accounting for possible interactions between the two predictors. Response variables were log-transformed to meet model linearity assumptions. We checked the linearity assumptions using the gvlma $\mathrm{R}$ package (gvlma function). Each model was subjected to backward selection of the independent variables using the step function (stats R-package), based on calculation of AIC values, to obtain the minimum adequate model. The significance of models' slopes was tested using the $F$ test. 1

\section{Results and discussion}

\section{Milk production}

Milk samples were collected from 50 ewes, 25 animals per group. At the beginning of the trial (July 8, 2016), CG sheep produced a total of 14.7 L/day of milk while the EG sheep yielded 15.3 L/day ( $\mathrm{P}$ two tail test equal to 0.7898 ), and thus there were no significant differences before the start of the feed supplementation experiment. Halfway through the experiment (July 21, 2016), CG sheep produced a total of $6.7 \mathrm{~L}$ /day of milk while the EG sheep gave $12 \mathrm{~L} /$ day (P two tail test 0.0013 ). At the end of the trial (August 9, 2016), CG sheep produced a total of $6.15 \mathrm{~L} /$ day of milk while the EG sheep produced $9.6 \mathrm{~L} /$ day $(\mathrm{P}$ 
two tail test 0.0368 ). Thus, there was a less pronounced decrease in milk production in EG sheep than in CG animals, according to what observed in a related study (Scocco et al. 2018). As expected, we observed that feed supplementation can positively affect milk yield, a finding that was also reported by Min et al. (2005), who found that an increased level of concentrate supplementation led to $22 \%$ greater milk yield.

\section{Chemical composition of milk and cheese}

The chemical composition of milk was assessed using 14 samples collected from a subgroup composed of the same sheep randomly chosen, from the different sampling days (Table 2S). Cheese chemical composition was assessed using 6 samples from respective different sampling days (Table 3S).

At the beginning of the study (July 8, 2016), the milk samples analysed displayed a fat content of $7.32 \%$, lactose of $4.35 \%$ and protein of $5.13 \%$ in CG and a fat content of 7.30 $\%$, lactose of $4.26 \%$ and protein of $5.08 \%$ in EG. At the end of the study (August 9, 2016), these levels were higher in EG milk $(9.17,4.19$ and $6.17 \%$, respectively) than in CG milk $(8.18,4.08$ and $5.90 \%$, respectively) though the difference was not statistically significant (Table 2S). This is consistent with the literature, which reports that usually the fat content of both cow and ewe milk is less influenced by the type of farming system and more by the animal diet, in particular the pasture diets supplemented with high levels of concentrates (Morand-Fehr et al. 2007). The literature indicates that protein content is more stable than fat content in milk (Morand-Fehr et al. 2007; Min et al. 2005) but our results pointed to some small differences (not statistically significant). In this study, we confirmed that changes in diet have a minimal effect on milk composition compared to milk yield (Min et al. 2005). 
We have obtained similar results for cheese. In fact, the cheese samples analysed at the beginning of the study (July 8,2016 ) displayed a fat content of $37.87 \%$ and protein of 26.21\%, in CG. At the end of the study (August 09, 2016), these levels were higher in EG milk (40.44and $25.95 \%$, for fat and protein respectively) than in CG milk (38.39 and $25.68 \%$, respectively) but the difference was not statistically significant (Table 3S).

\section{Method validation for the analysis of vitamins}

Calibration curves of the analytes were constructed by injecting into the HPLC-DAD $50 \mu 1$ of standard solutions at specific concentrations for each compound, namely, retinol 0.1, $0.5,1,5,10 \mathrm{mg} \mathrm{l}^{-1}$ and $\alpha$-tocopherol $0.5,1,5,10,25,50$ and $100 \mathrm{mg} \mathrm{l}^{-1}$. The correlation coefficients $\left(\mathrm{R}^{2}\right)$ of calibration curves of the analysed antioxidant compounds ranged from 0.9993 for $\alpha$-tocopherol to 0.9995 for retinol. Five replicates were performed for each concentration, and the relative standard deviations (RSDs) ranged from 0.15 to $0.98 \%$ for run-to-run precision, and from 1.9 to $3.9 \%$ for day-to-day precision. The limits of detection (LODs) and the limits of quantification (LOQs) of the two compounds, expressed in $\mathrm{mg}^{-1}$ and calculated in HPLC-DAD with standard solutions, were very low: 0.01 and 0.03 for retinol, 0.06 and 0.2 for $\alpha$-tocopherol, respectively. In addition, the mobile phase chosen for HPLC-DAD analyses (90\% acetonitrile and 10\% propanol, which is lipophilic), made it possible to analyse the two compounds in the same chromatographic step in a very short time (only 3 minutes of chromatographic run), much faster than those reported in other published methods (Chotyakul et al. 2014; Andrés et al. 2014).

\section{Analysis of retinol and a-tocopherol in milk and cheese}

Table 1 shows the retinol and $\alpha$-tocopherol content in milk from sheep reared on pasture (CG) and on pasture plus feed supplementation (EG) at five points during the height of the summer (July 8, 13, 21, 27 and August 9, 2016). At the beginning of the study, on July 8, 
in the $14 \mathrm{CG}$ milk samples, the average retinol levels were $0.73 \mathrm{mg} \mathrm{l}^{-1}$ and those of $\alpha$ tocopherol were $1.67 \mathrm{mg} \mathrm{l}^{-1}$, while in the $14 \mathrm{EG}$ milk samples, the average retinol levels were $0.74 \mathrm{mg} \mathrm{l}^{-1}$ and the average $\alpha$-tocopherol levels were $1.68 \mathrm{mg} \mathrm{l}^{-1}$. After just few days (on July 13, 2016), the levels of retinol and $\alpha$-tocopherol in CG milk remained substantially unchanged (0.72 and $1.75 \mathrm{mg} \mathrm{l}^{-1}$, respectively), while in EG milk they increased to 0.96 and $2.99 \mathrm{mg}^{-1}$ respectively. Throughout the study, in the $\mathrm{CG}$, the concentration of retinol remained stable, with a value of $0.74 \mathrm{mg} \mathrm{l}^{-1}$ at the end of the study (August 9, 2016), while there was a slight, but not statistically significant, increase in the level of $\alpha$-tocopherol at the end of the treatment $\left(1.92 \mathrm{mg} \mathrm{l}^{-1}\right)$. On the other hand, by the end of the study, the EG milk had significantly higher contents of retinol and $\alpha$-tocopherol than the CG milk. Specifically, in the August 9, 2016 EG milk samples, the retinol concentration had increased to $1.03 \mathrm{mg} \mathrm{l}^{-1}$, a statistically significant $(p<0.05)$ difference from the CG milk of the different time points, and the $\alpha$-tocopherol concentration had reached a value of $2.95 \mathrm{mg} \mathrm{l}^{-1}$ (an increase of more than $1 \mathrm{mg} \mathrm{l}^{-1}$ ), with a statistical significance of $p<0.01$ compared to CG.

Variation of retinol and $\alpha$-tocopherol concentrations was significantly explained by the interaction term between treatment and observation time, which accounted for the 38.55 and the $60.63 \%$ of variability (adj. $\mathrm{R}^{2}$ values, $p=2.6710^{-12}$ and $p<2.210^{-16}$, respectively) of the log-transformed concentrations. Detailed results are reported in Table $\mathbf{4 S}$.

Figure 1 shows an overlapping of 3 HPLC-DAD chromatograms: one was from a standard mixture solution, the second from July 8, 2016 CG milk sample, and the third from the August 9, 2016 EG milk sample.

Table 1 also shows information about cheese made from CG and EG milk $(n=6)$ at the beginning and at the end of the study. The levels of retinol and $\alpha$-tocopherol in cheese from the beginning of the study were 1.64 and $5.02 \mathrm{mg} \mathrm{kg}^{-1}$ in CG (July 08, 2016). These values 
remained constant in the cheese sample from CG milk: at the end of the study they were 1.68 for retinol and $4.64 \mathrm{mg} \mathrm{kg}^{-1}$ for $\alpha$-tocopherol. In contrast, these values were higher in the cheese samples made from EG milk at the end of the study: they rose to 2.02 and 5.77 $\mathrm{mg} \mathrm{kg} \mathrm{kg}^{-1}$ respectively, a statistically significant difference ( $p<0.05$ for both compounds) from the CG values. The literature provides little information about how the vitamin content in sheep milk may change as a result of changes in feeding systems. There are some studies on cows and some on goats. One work examined four studies on goats and reported that the various authors found higher $\alpha$-tocopherol content in milk from animals reared on a pasture system $\left(0.12,0.941,1.173\right.$ and $\left.0.932 \mathrm{mg} \mathrm{kg}^{-1}\right)$ compared to milk from goats kept indoors $\left(0.09,0.644,0.97\right.$ and $\left.0.645 \mathrm{mg} \mathrm{kg}^{-1}\right)$ (Galina and Haenlein 2004; Fedele et al. 2004; Pizzoferrato et al. 2000). Only one of these studies reported that this high $\alpha$-tocopherol content in milk persisted even when animals could feed ad libitum on concentrated feed in addition to the pasture diet (Pizzoferrato et al. 2000). One of these studies on goats contradicted our findings on sheep: Fedele et al. observed that supplementation of a pasture diet with concentrates reduced the retinol content in the milk of these goats (Fedele et al. 2004). To sum up, in our study on feeding systems and sheep milk and cheese, we have shown that the concentration of retinol and $\alpha$-tocopherol increased with feed supplementation $(p<0.05)$.

\section{Fatty acids in sheep milk and cheese}

Fatty acids were determined by gas chromatography coupled with flame ionization detection, and among them, the nineteen more abundant, well detected and well resolved (C4:0, C6:0, C8:0, C10:0, C12:0, C13:0, C14:0, C14:1, C15:0, C16:0, C16:1, C17:0, C17:1, C18:0, C18:1,n9, C18:2,n6, C18:3,n3, CLA (C18:2c9,t11), C20:0) were considered. The results, in terms of individual fatty acids percentages, saturated fatty acids (SFAs), monounsaturated fatty acids (MUFAs) and polyunsaturated fatty acids (PUFAs) classes 
percentages, and the ratio $n 6 / n 3$ PUFAs, are provided in Table 2. The different diets have a clear effect on the fatty acid composition of milk fat: the EG group, fed with supplemented diet, produced higher quality milk in terms of these important nutrients. In particular, on most of the sampling days, the total SFAs \% was lower in EG milk than in CG milk, even if the differences between the two groups were not statistically significant in this case. In general, the total MUFAs \% was very similar in the two groups during the whole sampling period. PUFAs \% was higher in the EG than the CG milk on four of the five sampling days; in particular, the difference was significant on July $21(p=0.048)$ and in the total $(p=0.049)$. Linolenic acid $(\mathrm{C} 18: 3, n 3) \%$, was actually significantly higher in EG compared to CG milk in the sampling of July 21 , when in fact also the ratio $n 6 / n 3$ PUFAs was lower $(p=0.034)$ in EG than in CG group. In each of the sampling day, linoleic acid was higher on average in EG than in CG and statistically significant when considering the total of the samples. The percentage of the conjugated linoleic acid (CLA, $\mathrm{C} 18: 2 c 9, t 11)$ detected did not differ significantly between the control and experimental groups in each of the samplings and in the total; however, the average CLA \% was higher in the EG on every sampling day except July 27, when it was identical in the two groups.

Fatty acid composition was assessed also in cheese produced in July before supplementation and in cheese from CG and EG produced in August with milk obtained after 1 month supplementation (Table 3). The most abundant fatty acid class, SFAs, was significantly higher $(p<0.05)$ in CG cheese before supplementation, with an average of $70.84 \%$, compared to values found in the two groups after one month of supplementation (66.59\% in CG and 67.24\% in EG), which did not differ significantly from each other. MUFAs were found in the average range of $22.18-24.68 \%$, PUFAs in the range of 3.73$4.15 \%$ and the $n 6 / n 3$-PUFAs ratio in the range $0.87-1.00$, and they did not significantly differ in the three groups investigated. Instead, percent content of CLA $(\mathrm{C} 18: 2 c 9, t 11)$ was 
significantly higher in cheeses produced in August than in cheeses produced in July. Thus, in the case of cheese, no significant effect produced by supplementation could be observed on the fatty acid composition. However, significant differences were found between cheese produced in July (before supplementation) and cheese produced in August, indicating a generally higher quality in terms of fatty acid composition, in cheeses produced in August, having significantly lower SFAs \% content and significantly higher CLA \% content, as compared to cheese produced in July.

In this regard, a study on milk from goats reared on pasture reported higher contents in C18 fatty acids, particularly PUFAs and CLA (Sanz Sampelayo et al. 2007), a finding that our study on sheep confirms, albeit with feed supplementation. Moreover, the observation that cheese produced in August contained significantly higher percentages of CLA than that produced in July is quite important, considering the antioxidative and anticarcinogenic properties of CLA, as well as its ability to stimulate immune response and to protect against arteriosclerosis (Mir et al. 1999).

\section{Volatile fraction in sheep cheese samples}

Volatile compounds identified in sheep cheese samples $(n=6)$ investigated by SPME-GCMS are shown in Table 4. A total of 19 compounds were detected, specifically, 9 carboxylic acids, 5 esters and 5 alcohols. The chemical classes with the highest area percentages were carboxylic acids $(84.50 \%-89.37 \%)$, followed by esters $(9.37-12.58 \%)$ and alcohols (3.04-5.46\%). The total area percentage of the identified compounds in the samples analysed is very high, ranging from 99.39 to $99.94 \%$.

Differences were found in the volatile compounds in the different samples. Regarding total carboxylic acids, in CG cheeses the percentage in the July 8 sample $\left(\mathrm{n}^{\circ} 1\right)$ was $84.50 \%$, while a higher value was found in the August 9 sample $\left(\mathrm{n}^{\circ} 2\right)$, which contained $89.37 \%$. Comparing the control and experimental cheeses on August 9, there was appreciable 
difference in the percentage of total carboxylic acids between cheese $n^{\circ} 2(89.37 \%)$ and cheese $\mathrm{n}^{\circ} 3$, which contained $81.90 \%$. Looking at specific carboxylic acids in the CG cheeses, the August 9 cheese contained higher levels of acetic acid, butanoic, octanoic and decanoic acids than July 8 cheese. However, in the August 9 EG cheese, these values were lower than or similar to those found in July 8 CG cheese and August 9 CG cheese.

Carboxylic acids can originate from three main biochemical pathways: lipolysis, proteolysis and lactose fermentation. Enzymes with lipolytic activity (esterases, lipases) may cause the release of linear-chain acids (butanoic, pentanoic, hexanoic, heptanoic, octanoic, decanoic and dodecanoic acids) (Delgado et al. 2010); instead, it is thought that acetic and propionic acids may have a microbial origin as a result of lactose fermentation, since changes in those acids have been associated with the growth of lactic acid and propionic bacteria. However, the shorter carboxylic acids can also be derived from ketones, esters and aldehydes by oxidation (Molimard and Spinnler, 1996), as the metabolic products of lactose metabolism, deamination of amino acids and possibly lipid oxidation. It is known that the above mentioned carboxylic acids are negative odourants; in fact, acetic acid is associated with a "sour-vinegar" odour (Caprioli et al. 2016), and may explain the slightly acid taste of these cheeses; butanoic, octanoic and decanoic acids, as well as others, are associated with the "pungent", "rancid", "sweat", and "metal" odour qualities (Rodriguez-Campos et al. 2011; Rodriguez-Campos et al. 2012).

Differences were also found in the total esters in the different samples, but unlike the carboxylic acids, there was a decrease in the percentages of esters in the CG cheeses: the July 8 CG cheese (sample $n^{\circ} 1$ ) contained $10.60 \%$, while the August 9 CG cheese $\left(n^{\circ} 2\right)$ had 9.37\%. Instead, comparing control and experimental cheeses, the percentages of esters increased after the month of supplementary feeding: August 9 EG cheese (sample $n^{\circ} 3$ ) contained $12.58 \%$. Looking at specific esters, specifically ethyl butanoate, ethyl hexanoate 
and ethyl octanoate, for the control group there was a drop in the percentages of these compounds after a month: the August CG cheese contained less than the July CG cheese. However, for the experimental group, the content in these specific esters was higher in the August EG cheese $\left(n^{\circ} 3\right)$ than in $n^{\circ} 1$ and $n^{\circ} 3$ cheeses. Esters were the second most abundant compounds isolated in the headspace of the cheeses analysed in our study, and due to their high amount, probably contribute to the overall flavour of cheese, as they have low detection thresholds (Delgado et al. 2010). The decrease of these esters in the August 9 CG cheese could be explained by the increase in the carboxylic acid in this cheese, and vice-versa. The highest percentages of esters were found in the August 9 EG cheese $\left(n^{\circ} 3\right)$; this is a positive factor, as they are associated with the pleasant odour qualities of fruit, pineapple, apple and banana. Finally, there was a decrease in the percentages of total alcohols in the CG cheeses. The July 8 CG cheese $\left(n^{\circ} 1\right)$ contained $5.29 \%$, while the August 9 CG cheese $\left(\mathrm{n}^{\circ} 2\right)$ had 3.04\%. Instead, comparing CG and EG cheeses, the August 9 EG cheese (sample $n^{\circ} 3$ ) had a higher percentage of total alcohols $(5.46 \%)$ than the CG cheeses. Alcohols are generally responsible for producing desirable flavour notes (Caprioli et al. 2016); one of interest is 3-methylbutanol, which is associated with a malty-chocolate odour.

\section{Conclusions}

This study highlights the important effects of feeding supplementation on the composition and quality of milk and cheese from sheep grazing on dry pasture, more in terms of specific compounds (retinol, $\alpha$-tocopherol, fatty acids) and milk production than in terms of nutritional composition. For the first time, positive effects on the volatile composition were found in EG cheese. In fact, EG samples displayed a lower content of carboxylic acid associated with the "pungent", "rancid", "sweat", and "metal" odour with respect to CG. It is to be hoped that our results documenting feeding-related variations in the chemical 
features of milk and cheese will prove useful for those developing solutions to adapt the sub-Mediterranean semi-extensive farming system to the forecasted global warmingrelated climatic changes. Our results indicate that the expected worsening of pasture features could have deleterious effects on the chemical characteristics of sheep milk products. This in turn could have negative ramifications for the economic sustainability of pastoral systems, which are a key part of EU policies to counter the depopulation of mountain communities and the loss of biodiversity in these lands. In this perspective, the enhanced nutraceutical value, due, for example, to the major anti-oxidant vitamin $\mathrm{A}$ and $\mathrm{E}$ contents, could be communicated to the consumers in order to promote the farm products, enhancing the farm income.

\section{Acknowledgements}

This work was financially supported by the University of Camerino (Fondo di Ateneo per la Ricerca 2014-2015) assigned to Prof. Andrea Catorci. The authors are grateful to Caseificio Di Pierantonio (Belforte del Chienti, Macerata, Italy) for providing samples, and to Sheila Beatty for editing the English usage in the manuscript.

\section{Disclosure statement}

The authors report no conflicts of interest. The authors alone are responsible for the content and writing of this article. 


\section{References}

Agabriel C, Coulon J. B, Brunschwig G, Sibra C, Nafidi C. 1995. Relations entre la qualité du lait livré et les caracteristiques des exploitations (relation between quality of milks delivered to dairies and characteristics of farms producing these milks). INRA Productions Animales. $8: 251-258$.

Agabriel C, Coulon J. B, Journal C, De Rancourt B. 2001. Composition chimique du lait et systemes de production dans les exploitations du Massif Central (chemical composition of milk and production systems in farms of French Central Mountains). INRA Productions Animales. 14 : 119-128.

Andrés V, Villanueva M. J, Tenorio M. D. 2014. Simultaneous determination of tocopherols, retinol, ester derivatives and b-carotene in milk- and soy-juice based beverages by HPLC with diode-array detection. LWT - Food Science and Technology. 58: $557-562$.

AOAC International. 2000. Official methods of analysis of AOAC International, (17th ed.), Gaithersburg, MD, USA: AOAC.

Biggs D.A. 1978. Instrumental infrared estimation of fat, protein, and lactose in milk: collaborative study. Journal - Association of Official Analytical Chemists. 61: 1015-1034.

Boyazoglu J, Morand-Fehr P. 2001. Mediterranean dairy sheep and goat products and their quality. A critical review. Small Ruminant Research. 40: 1-11.

Caprioli G, Fiorini D, Maggi F, Nicoletti M, Ricciutelli M, Toniolo C, Prosper B, Vittori S, Sagratini G. 2016. Nutritional composition, bioactive compounds and volatile profile of 
cocoa beans from different regions of Cameroon. International Journal of Food Sciences and Nutrition. 67: 422-430.

Chotyakul N, Pateiro-Moure M, Saraiva J. A, Torres J. A, Perez-Lamela C. 2014. Simultaneous HPLC-DAD quantification of vitamins A and E content in raw, pasteurized, and UHT cow's milk and their changes during storage. European Food Research and Technology. 238: 535-547.

Coulon J. B, Rock E, Noel Y. 2003. Caracteristiques nutritionnelles des produits laitiers et variations selon leur origine (dietary characteristics and variations of milk products depending on their origin). INRA Productions Animales. 16: 275-278.

Delgado F. J, González-Crespo J, Cava R, García-Parra J, Ramírez R. 2010. Characterisation by SPME-GC-MS of the volatile profile of a Spanish soft cheese P.D.O. Torta del Casar during ripening. Food Chemistry. 118: 182-189.

Fávaro R. M. D, Iha M. H, Bianchi M. L. P. 2003. Liquid chromatographic determination of geometrical retinol isomers and carotene in enteral feeding formulas. Journal of Chromatography A. 1021: 125-132.

Fedele V, Claps S, Rubino R, Manzi P, Marconi S, Pizzoferrato L. 2004. Seasonal variation in retinol concentration of goat milk associated with grazing compared to indoor feeding. South African Journal of Animal Science. 34: 148-150.

Galina M, Haenlein G. F. W. 2004. Cheese quality and human health. In: Proc. Abstr. 8th Intern. Conf. Goats, Pretoria (South Africa). 4-9 July 2004, P019, p. 42.

Giorgi F, Lionello P. 2008. Climate change projections for the Mediterranean region. Global and Planetary Change. 63: 90-104. 
Ichihara, Shibahara A, Yamamoto K, Nakayama T. 1996. An improved method for rapid analysis of the fatty acids of glycerolipids. Lipids, 31: 535-539.

Jenness R. 1980. Composition and characteristics of goat milk: review 1968-1979. Journal of Dairy Science. 63, 10: 1605-1630.

Mercati F, Maranesi M, Dall'Aglio C, Petrucci L, Pasquariello R, Tardella F.M, De Felice E, Scocco P. 2018. Apelin System in Mammary Gland of Sheep Reared in Semi-Natural Pastures of the Central Apennines. Animals. 8: 223; doi:10.3390/ani8120223

Min B. R, Hart S. P, Sahlu T, Satter L. D. 2005. The Effect of Diets on Milk Production and Composition, and on Lactation Curves in Pastured Dairy Goats. Journal of Dairy Science. 88: 2604-2615.

Mir Z, Goonewardene L. A, Okine E, Jaegar S, Scheer H. D. 1999. Effect of feeding canola oil on constituents, conjugated linoleic acid (CLA) and long chain fatty acids in goats milk. Small Ruminant Research. 33: 137-143.

Molimard P, Spinnler H. 1996. Compounds involved in the flavour of surface moldripened cheeses: origins and properties. Journal of Dairy Science. 79: 169-184.

Morand-Fehr P, Fedele V, Decandia M, Le Frileux Y. 2007. Influence of farming and feeding systems on composition and quality of goat and sheep milk. Small Ruminant Research. 68: 20-34.

Nardone A, Ronchi B, Lacetera N, Ranieri M.S, Bernabucci U. 2010. Effects of climate changes on animal production and sustainability of livestock systems. Livestock Science. 130: 57-69. 
Pirisi A, Piredda G, Scintu M.F, Fois N. 2001. Effect of feeding diets on quality characteristics of milk and cheese produced from Sarda dairy ewes. Options Mediterranèennes. 46: 115-119.

Pizzoferrato L, Manzi P, Rubino R, Fedele V, Pizillo M. 2000. Degree of antioxydant protection in goat milk and cheese: the effect of feeding systems. In: 7th International Conference on Goats, Tours (Fr), 15-21 May 2000, pp. 580-582.

Raynal-Ljutovac K, Lagriffoul G, Paccard P, Guillet I, Chilliard Y. 2008. Composition of goat and sheep milk products: An update. Small Ruminant research. 79: 57-72.

Remeuf F, Cossin V, Denvin C, Lenoir J, Tomassone R. 1991. Relationships between physico-chemical characteristics of milks and their cheese making properties. Lait. 71: $397-421$.

Rodriguez-Campos J, Escalona-Buend H. B, Orozco-Avila I, Lugo-Cervantes E, JaramilloFlores E. 2011. Dynamics of volatile and non-volatile compounds in cocoa (Theobroma cacao L.) during fermentation and drying processes using principal components analysis. Food Research International. 44: 250-258.

Rodriguez-Campos J, Escalona-Buendía H. B, Contreras-Ramos S. M, Orozco-Avila I, Jaramillo-Flores E, Lugo-Cervantes E. 2012. Effect of fermentation time and drying temperature on volatile compounds in cocoa. Food Chemistry. 132: 277-288.

Rubino R, Morand-Fehr P, Rinieri C, Peraza C, Sarti F. M. 1999. Typical products of the small ruminant sector and the factors affecting their quality. Small Ruminant research. 34: 289-302. 
Russel A, Gunn R. G, Doney, J.M., 1969. Subjective assessment of body fat in live sheep. The Journal of Agricultural Science. 72: 451-454.

Sanz Sampelayo M. R, Chilliard Y, Schmidely P.H, Boza J. 2007. Influence of type of diet on the fat constituents of goat and sheep milk. Small Ruminant Research. 68: 42-63.

Scocco P, Mercati F, Brusaferro A, Ceccarelli P, Belardinelli C, Malfatti A. 2013. Keratinization degree of rumen epithelium and body condition score in sheep grazing on Brachipodium rupestre. Veterinaria Italiana. 49: 211-217.

Scocco P, Piermarteri K, Malfatti A, Tardella F.M, Catorci A. 2016a. Increase of drought stress negatively affects the sustainability of extensive sheep farming in sub-Mediterranean climate. Journal of Arid Environments. 128: 50-58.

Scocco P, Piermarteri K, Malfatti A, Tardella F.M, Catorci A. 2016b. Effects of summer rainfall variations on sheep body state and farming sustainability in sub-Mediterranean pastoral systems. Spanish Journal of Agricultural Research. 14: 3, e03SC02.

Scocco P, Rivaroli S, Mercati F, Tardella F.M, Malfatti A, De Felice E, Catorci A. 2018. Anatomy for economy: starting from the rumen keratinization degree to enhance the farm income. Food Economy. 20: 1-12. Doi: 10.3280/ECAG2017-002-002. 


\section{Figure captions}

Figure 1.

HPLC-DAD chromatograms reported at 326 and $292 \mathrm{~nm}$ for retinol and $\alpha$-tocopherol respectively, corresponding to A) standard mixture solution B) milk samples from CG sheep (July 8, 2016) and C) milk samples from EG sheep (August 9, 2016). 
retinol

A)

International Journal of Food Sfiẹces \& Nutrition

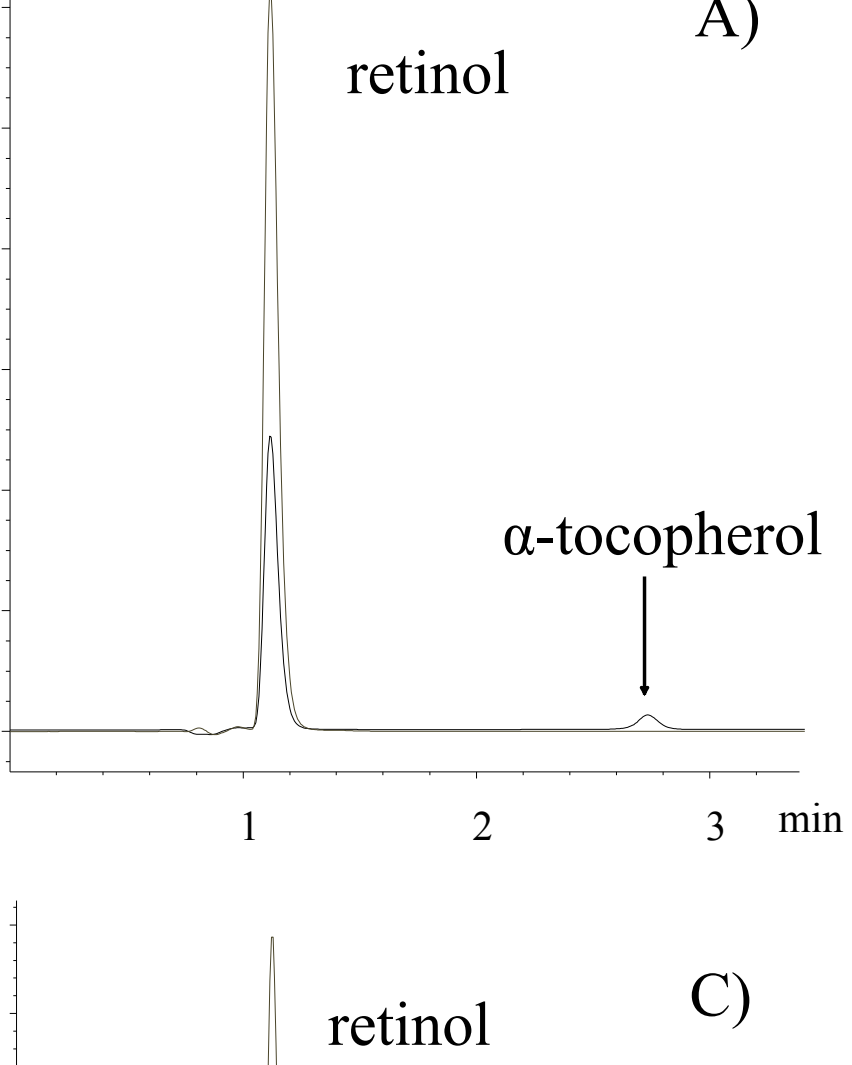

$\alpha$-tocopherol

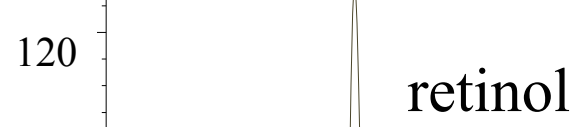

B)

\section{retinol}

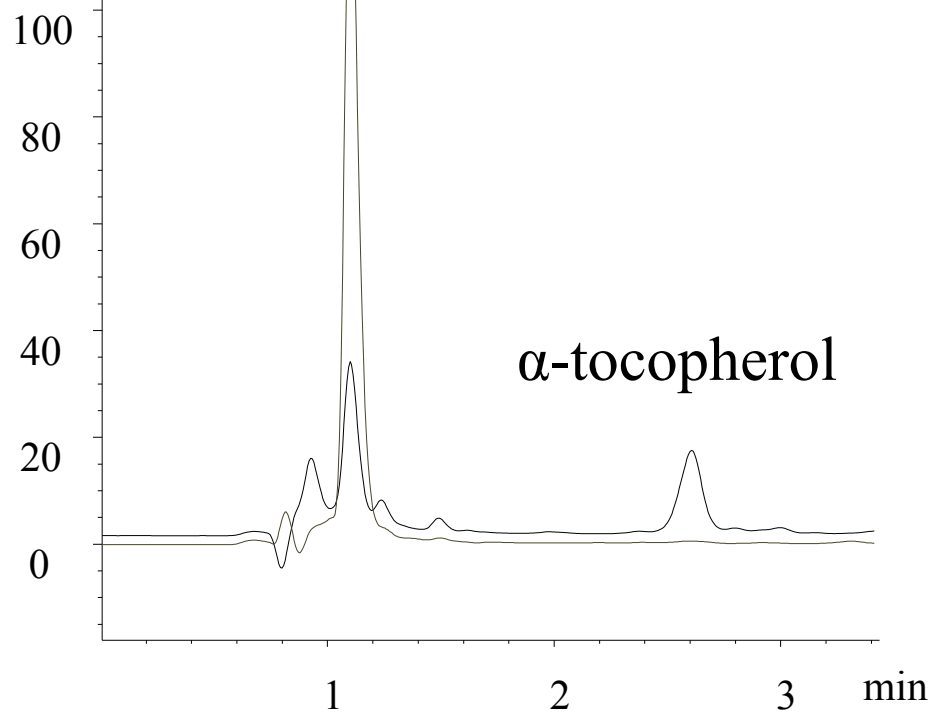

Figure 1. HPLC-DAD chromatograms reported at 326 and $292 \mathrm{~nm}$ for retinol and $\alpha$-tocopherol respectively, corresponding to A) standard mixture solution B) milk samples from CG sheep (July 8, 2016) and C) milk samples from EG sheep (August 9, 2016). 
Table 1. Retinol and $\alpha$-tocopherol in milk and cheese from sheep reared on "pasture" (control group, CG) or on "pasture plus feed supplementation" (experimental group, EG) farming system (data are expressed in $\mathrm{mg} \mathrm{l}^{-1}$ for milk and in $\mathrm{mg} \mathrm{kg}^{-1}$ for cheese).

\begin{tabular}{cccc}
\hline MILK time points & Group & Retinol & $\alpha$-tocopherol \\
\hline \multirow{2}{*}{ July 08, 2016 } & CG $(n=14)$ & $0.73^{\mathrm{a}} \pm 0.12$ & $1.67^{\mathrm{a}} \pm 0.34$ \\
& EG $(n=14)$ & $0.74^{\mathrm{a}} \pm 0.12$ & $1.68^{\mathrm{a}} \pm 0.35$ \\
\hline \multirow{2}{*}{ July 13, 2016 } & CG $(n=14)$ & $0.72^{\mathrm{a}} 0.06$ & $1.75^{\mathrm{a}} \pm 0.56$ \\
& EG $(n=14)$ & $0.96^{\mathrm{b}} \pm 0.22$ & $2.99^{\mathrm{b}} \pm 0.70$ \\
\hline \multirow{2}{*}{ July 21, 2016 } & CG $(n=14)$ & $0.76^{\mathrm{a}} \pm 0.06$ & $1.94^{\mathrm{a}} \pm 0.37$ \\
\hline \multirow{2}{*}{ July 27, 2016 } & EG $(n=14)$ & $0.91^{\mathrm{b}} \pm 0.12$ & $2.94^{\mathrm{b}} \pm 0.31$ \\
\hline \multirow{2}{*}{ August 09, 2016 } & CG $(n=14)$ & $0.76^{\mathrm{a}} \pm 0.09$ & $1.93^{\mathrm{a}} \pm 0.49$ \\
& EG $(n=14)$ & $0.94^{\mathrm{b}} \pm 0.18$ & $3.01^{\mathrm{b} \pm 0.43}$ \\
\hline CHEESE time points & CG $(n=14)$ & $0.74^{\mathrm{a}} \pm 0.07$ & $1.92^{\mathrm{a}} \pm 0.32$ \\
\hline July 08, 2016 & EG $(n=14)$ & $1.03^{\mathrm{b}} \pm 0.21$ & $2.95^{\mathrm{b}} \pm 0.32$ \\
\hline \multirow{2}{*}{ August 09, 2016 } & Group & Retinol $^{2}$ & $\alpha$-tocopherol \\
\hline
\end{tabular}

${ }^{\mathrm{a}, \mathrm{b}}$ For milk different letters in the same column indicate significant differences $(p<0.05$ for retinol) and ( $p<0.01$ for $\alpha$-tocopherol) between experimental and control group.

${ }^{\mathrm{c}, \mathrm{d}}$ For cheese different letters in the same column indicate significant differences $(p<0.05)$ 
Table 2. Average fatty acid composition in milk from each sampling day and from the total, reported in terms of $\%$ saturated fatty acids (\% SFAs), $\%$ monounsaturated fatty acids (MUFAs) , \% polyunsaturated fatty acids (PUFAs), and individual percentages of selected fatty acids: linoleic acid (C18:2,n6), linolenic acid $(\mathrm{C} 18: 3, n 3)$ and conjugated linoleic acid (CLA, C18:2c9,t11). The ratio $n 6 / n 3$ PUFA is also reported.

\begin{tabular}{|c|c|c|c|c|c|c|c|c|c|c|c|c|c|c|c|}
\hline \multirow[t]{2}{*}{ Sampling day } & & \multicolumn{2}{|c|}{$\%$ SFAs } & \multicolumn{2}{|c|}{$\%$ MUFAs } & \multicolumn{2}{|c|}{$\%$ PUFAs } & \multicolumn{2}{|c|}{$\% \mathrm{C} 18: 2, n 6$} & \multicolumn{2}{|c|}{$\% \mathrm{C} 18: 3, n 3$} & \multicolumn{2}{|c|}{$n 6 / n 3$ PUFA } & \multicolumn{2}{|c|}{$\begin{array}{c}\text { CLA }(\mathrm{C} 18: 2 c 9, t 11) \\
\%\end{array}$} \\
\hline & & EG & $\mathrm{CG}$ & EG & $\mathrm{CG}$ & EG & $\mathrm{CG}$ & EG & CG & EG & $\mathrm{CG}$ & EG & $\mathrm{CG}$ & EG & $\mathrm{CG}$ \\
\hline \multirow[t]{3}{*}{ July 8, 2016} & $\%$ average & 68.23 & $69.82 \mathrm{ab}$ & 26.33 & $25.76^{a b}$ & $4.28^{\mathrm{a}}$ & $3.42^{\mathrm{ab}}$ & $2.42^{\mathrm{a}}$ & $2.03^{a b}$ & $1.87^{\mathrm{a}}$ & $1.39^{\mathrm{ab}}$ & $1.31^{\mathrm{a} \#}$ & 1.49 ab $\S$ & 1.15 & $1.00^{\mathrm{a}}$ \\
\hline & & 4.51 & 4.92 & 3.61 & 3.97 & 0.56 & 0.91 & 0.25 & 0.50 & 0.32 & 0.42 & 0.11 & 0.10 & 0.44 & 0.14 \\
\hline & $\%$ RSD & 6.61 & 7.05 & 13.69 & 15.41 & 12.98 & 26.57 & 10.15 & 24.49 & 17.07 & 29.99 & 8.18 & 6.72 & 38.54 & 13.58 \\
\hline \multirow[t]{3}{*}{ July 13, 2016} & $\%$ average & 67.71 & $67.06^{\mathrm{a}}$ & 26.74 & $27.36^{\mathrm{a}}$ & $4.17^{\mathrm{a}}$ & $4.19^{b}$ & $2.42^{\mathrm{a}}$ & $2.34^{\mathrm{b}}$ & $1.74^{\mathrm{a}}$ & $1.85^{\mathrm{b}}$ & $1.40^{\mathrm{a}}$ & $1.29^{\mathrm{a}}$ & 1.39 & $1.38 \mathrm{bd}$ \\
\hline & SD & 3.40 & 4.34 & 3.15 & 3.28 & 0.23 & 0.98 & 0.17 & 0.48 & 0.11 & 0.52 & 0.11 & 0.15 & 0.32 & 0.26 \\
\hline & $\%$ RSD & 5.02 & 6.47 & 11.80 & 11.98 & 5.62 & 23.40 & 7.19 & 20.52 & 6.44 & 27.84 & 8.12 & 11.67 & 23.32 & 18.57 \\
\hline \multirow[t]{3}{*}{ July 21, 2016} & $\%$ average & 69.52 & 70.29 ab & 26.06 & $25.73 \mathrm{ab}$ & $3.21^{\mathrm{b} \#}$ & $2.78^{a} \S$ & $2.03^{b}$ & $1.82^{\mathrm{ab}}$ & $1.18^{\mathrm{b} \#}$ & 0.96 acd $\S$ & $1.73^{b c \#}$ & $1.90^{\mathrm{cd} \S}$ & 1.22 & $1.20^{\mathrm{abcd}}$ \\
\hline & & 3.38 & 1.96 & 2.97 & 1.59 & 0.18 & 0.38 & 0.13 & 0.22 & 0.08 & 0.16 & 0.11 & 0.11 & 0.32 & 0.19 \\
\hline & $\%$ RSD & 4.87 & 2.79 & 11.38 & 6.17 & 5.77 & 13.56 & 6.33 & 11.82 & 6.73 & 16.98 & 6.17 & 5.57 & 25.99 & 15.86 \\
\hline \multirow[t]{3}{*}{ July 27, 2016} & $\%$ average & 73.37 & $73.72^{b}$ & 22.36 & $22.52^{b}$ & $3.12^{\mathrm{b}}$ & $2.61^{\mathrm{a}}$ & $2.03^{b}$ & $1.75^{\mathrm{a}}$ & $1.09^{\mathrm{b}}$ & $0.86^{\mathrm{c}}$ & $1.87^{\mathrm{cd}}$ & $2.07^{\mathrm{d}}$ & 1.15 & $1.15^{\mathrm{abc}}$ \\
\hline & SD & 3.67 & 1.77 & 3.19 & 1.34 & 0.38 & 0.46 & 0.22 & 0.27 & 0.17 & 0.20 & 0.15 & 0.25 & 0.23 & 0.16 \\
\hline & $\%$ RSD & 5.00 & 2.41 & 14.26 & 5.95 & 12.33 & 17.77 & 10.81 & 15.34 & 16.04 & 23.44 & 7.97 & 12.08 & 19.75 & 13.82 \\
\hline \multirow[t]{3}{*}{ August 9, 2016} & $\%$ average & 69.68 & $71.37^{\mathrm{ab}}$ & 24.42 & $23.49^{b}$ & $4.37^{\mathrm{a}}$ & $3.68^{a b}$ & $2.70^{\mathrm{a}}$ & $2.30^{\mathrm{ab}}$ & $1.67^{\mathrm{a}}$ & $1.38^{\mathrm{abcd}}$ & $1.62^{\mathrm{b}}$ & $1.68^{\mathrm{bc}}$ & 1.53 & $1.46^{\mathrm{d}}$ \\
\hline & & 2.63 & 1.67 & 2.06 & 1.20 & 0.49 & 0.61 & 0.33 & 0.33 & 0.18 & 0.28 & 0.11 & 0.16 & 0.21 & 0.10 \\
\hline & $\%$ RSD & 3.77 & 2.35 & 8.44 & 5.09 & 11.23 & 16.49 & 12.30 & 14.36 & 10.84 & 20.58 & 6.88 & 9.48 & 13.57 & 6.58 \\
\hline \multirow[t]{3}{*}{ All the samples } & $\%$ average & 69.83 & 70.45 & 25.08 & 24.97 & $3.79^{\#}$ & $3.34^{\S}$ & $2.31^{\#}$ & $2.05^{\S}$ & 1.48 & 1.29 & 1.61 & 1.69 & 1.30 & 1.24 \\
\hline & SD & 3.74 & 3.70 & 3.17 & 2.92 & 0.66 & 0.88 & 0.34 & 0.42 & 0.35 & 0.48 & 0.23 & 0.32 & 0.31 & 0.23 \\
\hline & $\%$ RSD & 5.36 & 5.25 & 12.64 & 11.69 & 17.44 & 26.33 & 14.84 & 20.60 & 23.81 & 37.10 & 14.44 & 19.07 & 23.79 & 18.73 \\
\hline
\end{tabular}

EG: experimental group (grazing plus supplemented diet), $n=14$; CG: control group (grazing) (n=14). SD: standard deviation; RSD: relative standard deviation. Two sampling groups within the same column are significantly different $(p<0.05$, one-way ANOVA) for the parameter considered if their average values do not show superscript letters in common. Experimental group and control group within the same row are significantly different ( $p<0.05$, one-way ANOVA) if different superscript symbols are reported on their average values for the parameter considered. 
Table 3. Average fatty acid composition in cheese at the beginning and at the end of the study, reported in terms of saturated fatty acids (SFAs), monounsaturated fatty acids (MUFAs) and polyunsaturated fatty acids (PUFAs) $\%$ composition and in terms of selected individual fatty acids $\%$ composition. The ratio $n 6 / n 3$ PUFAs is also reported.

\begin{tabular}{|c|c|c|c|c|c|c|}
\hline & \multirow{2}{*}{\multicolumn{2}{|c|}{$\begin{array}{c}\text { July } 08,2016 \\
\text { CG }\end{array}$}} & \multicolumn{4}{|c|}{ August 09,2016} \\
\hline & & & \multicolumn{2}{|c|}{$\mathrm{CG}$} & \multicolumn{2}{|c|}{ EG } \\
\hline & $\%$ average & $\% \mathrm{RSD}$ & $\%$ average & $\%$ RSD & $\%$ average & $\%$ RSD \\
\hline SFAs & $70.84^{\mathrm{a}}$ & 3.23 & $66.59^{b}$ & 4.27 & $67.24^{\mathrm{b}}$ & 3.51 \\
\hline MUFAs & 22.18 & 6.22 & 24.68 & 7.70 & 23.21 & 6.43 \\
\hline PUFAs & 3.73 & 7.39 & 4.15 & 8.13 & 4.13 & 10.30 \\
\hline $\mathrm{C} 18: 2, n 6$ & 1.20 & 8.91 & 1.18 & 11.77 & 1.31 & 17.04 \\
\hline $\mathrm{C} 18: 3, n 3$ & 1.21 & 6.19 & 1.36 & 8.38 & 1.31 & 5.10 \\
\hline CLA $(\mathrm{C} 18: 2 c 9, t 11)$ & $1.32^{\mathrm{a}}$ & 7.60 & $1.61^{\mathrm{b}}$ & 8.03 & $1.52^{\mathrm{b}}$ & 9.44 \\
\hline$n 6 / n 3$-PUFAs & 0.99 & 2.82 & 0.87 & 11.15 & 1.00 & 11.97 \\
\hline
\end{tabular}

EG: experimental group (fed supplemented diet), $n=6$. CG: control group, $n=6$

RSD: relative standard deviation. Significant differences exist $(p<0.05$, one way ANOVA) between the groups for the percentage of a fatty acid or a fatty acid class or $n 6 / n 3$-PUFAs ratio, if different uppercase letters are reported on their average values for the parameter considered. 
Table 4. Volatile components identified in cheese samples and related percentages of peak area values obtained using the PDMS/DVB/CAR fiber in the HS-SPME-GC-MS analysis $(n=6)$.

\begin{tabular}{|c|c|c|c|c|c|c|}
\hline N. & Component $\mathrm{t}^{\mathrm{a}, \mathrm{b}}$ & Ret. Time (min.) & $\begin{array}{c}\text { ID } \\
\text { methods }\end{array}$ & $\begin{array}{c}\text { Cheese } 1 \\
\text { July } 08,2016\end{array}$ & $\begin{array}{c}\text { Cheese } 2 \\
\text { August 09, } 2016\end{array}$ & $\begin{array}{c}\text { Cheese } 3 \\
\text { August 09, } 2016\end{array}$ \\
\hline & & & & $\mathrm{CG}^{\mathrm{d}}$ & CG & EG \\
\hline & & & & $n=6$ & $n=6$ & $n=6$ \\
\hline 1 & Ethanol & 8.63 & RI, TI & 1.91 & 1.38 & 2.98 \\
\hline 2 & 2-butanol & 12.18 & RF, RI, TI & 0.91 & 0.16 & 0.59 \\
\hline 3 & ethyl butanoate & 12.29 & RF, RI, TI & 1.29 & 0.92 & 1.65 \\
\hline 4 & propanoic acid & 16.34 & RF, RI, TI & 0.15 & 0.12 & 0.24 \\
\hline 5 & 2 propen-1-ol & 16.55 & RI, TI & 0.43 & 0.15 & 0.07 \\
\hline 6 & 3-methyl-1-butanol & 21.52 & RF, RI, TI & 1.42 & 0.82 & 1.33 \\
\hline 7 & ethyl hexanoate & 22.48 & RF, RI, TI & 7.60 & 6.66 & 9.12 \\
\hline 8 & isoamyl butanoate & 24.22 & RI, TI & 0.58 & 0.55 & 0.40 \\
\hline 9 & ethyl octanoate & 33.24 & RF, RI, TI & 0.69 & 0.60 & 0.94 \\
\hline 10 & acetic acid & 33.67 & RF, RI, TI & 9.31 & 10.24 & 9.36 \\
\hline 11 & butanoic acid & 40.96 & RF, RI, TI & 31.52 & 33.25 & 33.62 \\
\hline 12 & Ethyl decanoate & 41.36 & RI, TI & 0.44 & 0.65 & 0.48 \\
\hline 13 & 3-methylbutanoic acid & 41.95 & RF, RI, TI & 0.43 & 0.08 & 0.10 \\
\hline 14 & pentanoic acid & 43.11 & RI, TI & 0.42 & 0.44 & 0.43 \\
\hline 15 & hexanoic acid & 44.56 & RI, TI & 26.43 & 26.47 & 25.02 \\
\hline 16 & phenyl ethyl alcohol & 45.35 & RI, TI & 0.62 & 0.53 & 0.48 \\
\hline 17 & heptanoic acid & 45.64 & RI, TI & 0.30 & 0.31 & 0.23 \\
\hline 18 & octanoic acid & 46.54 & RF, RI, TI & 9.88 & 10.54 & 8.60 \\
\hline 19 & decanoic acid & 48.15 & RI, TI & 5.06 & 5.94 & 4.31 \\
\hline & Carboxylic acids & & & 84.50 & 89.37 & 81.90 \\
\hline & Esters & & & 10.60 & 9.37 & 12.58 \\
\hline & Alcohols & & & 5.29 & 3.04 & 5.46 \\
\hline & $\begin{array}{l}\text { identified compounds } \\
\text { total peak area value [\%] }\end{array}$ & & & 99.39 & 99.78 & 99.94 \\
\hline
\end{tabular}

40

41

42

43 a Compounds are listed in order of their elution from a DB-WAX GC column (detection at GC/MS); percentage values are 44 45 means of five determinations.

46 bRelative standard deviations \% ranged from 0.17 to $5.81 \%$.

47

$48{ }^{c}$ Method of identification: RF, mass spectrum and retention time identical with a reference compound; RI, mass spectrum and 49 retention index from literature in agreement; TI, tentative identification by mass spectrum.

$51^{\text {d }}$ Cheese from sheep reared on "pasture" (control group, CG) or on "pasture plus feed supplementation" 52 53 (experimental group, EG)

54

55

56

57

58

59

60 
Table 1S. Chemical composition of the feed supplementation (\%).

\begin{tabular}{|c|c|}
\hline Items & Total Feed \\
\hline Dry matter & 88.5 \\
\hline Crude protein & 10 \\
\hline Lysine & 0.3 \\
\hline Methionine & 0.16 \\
\hline Tryptophan & 0.09 \\
\hline Fat & 3.0 \\
\hline Crude fibre & 3.7 \\
\hline Ash & 1.8 \\
\hline $\mathrm{Ca}$ & 0.03 \\
\hline $\mathrm{P}$ & 0.31 \\
\hline Starch & 57.5 \\
\hline Free sugars & 2.1 \\
\hline NDF (\% DM) & 12.5 \\
\hline Lignins & 1.3 \\
\hline UFL (energy) & 1.05 \\
\hline \multicolumn{2}{|l|}{ Fatty acids (\%) } \\
\hline C14:0 myristic acid & 0.010 \\
\hline C16:0 palmitic acid & 0.326 \\
\hline C16:1 palmitoleic acid & 0.006 \\
\hline C18:0 stearic acid & 0.038 \\
\hline C18:1 oleic acid & 0.442 \\
\hline C18:2 linoleic acid & 1.214 \\
\hline C18:3 linolenic acid & 0.063 \\
\hline \multicolumn{2}{|l|}{ Vitamins } \\
\hline vitamin $\mathrm{E}(\alpha$-tocoferol) $(\%)$ & 1.809 \\
\hline vitamin A (retinol) $(\mu \mathrm{g} / 100 \mathrm{~g})$ & 66.738 \\
\hline
\end{tabular}


Table 2S. Chemical composition of milk (data of fat, lactose, protein, casein are expressed in \%) from sheep reared on "pasture" (control group, CG) or on "pasture plus feed supplementation" (experimental group, EG) (RSD\% ranged from 1.05 to $6.71 \%$ ).

\begin{tabular}{|c|c|c|c|c|c|c|c|c|c|c|}
\hline \multirow{3}{*}{$\begin{array}{c}\text { Analysis } \\
\text { Items }^{\mathrm{a}}\end{array}$} & \multicolumn{2}{|c|}{ July 8, 2016} & \multicolumn{2}{|c|}{$\begin{array}{c}\text { July 13, } \\
2016\end{array}$} & \multicolumn{2}{|c|}{$\begin{array}{c}\text { July } 21 \text {, } \\
2016\end{array}$} & \multicolumn{2}{|c|}{$\begin{array}{c}\text { July } 27, \\
2016\end{array}$} & \multicolumn{2}{|c|}{$\begin{array}{c}\text { August 9, } \\
2016\end{array}$} \\
\hline & $\mathrm{CG}$ & EG & $\mathrm{CG}$ & EG & $\mathrm{CG}$ & EG & $\mathrm{CG}$ & EG & $\mathrm{CG}$ & $\mathrm{EG}$ \\
\hline & $\mathrm{n}=14$ & $\mathrm{n}=14$ & $n=14$ & $n=14$ & $n=14$ & $n=14$ & $n=14$ & $n=14$ & $n=14$ & $n=14$ \\
\hline Fat & 7.32 & 7.30 & 9.73 & 9.15 & 7.23 & 7.26 & 7.54 & 7.67 & 8.18 & 9.17 \\
\hline Lactose & 4.35 & 4.26 & 4.23 & 4.35 & 4.36 & 4.44 & 4.28 & 4.39 & 4.08 & 4.19 \\
\hline Protein & 5.13 & 5.08 & 5.25 & 5.21 & 5.24 & 5.26 & 5.50 & 5.43 & 5.90 & 6.17 \\
\hline Casein & 4.00 & 4.05 & 4.09 & 4.04 & 3.98 & 4.00 & 4.24 & 4.19 & 5.53 & 4.80 \\
\hline Urea (mg/dl) & 36.23 & 36.29 & 38.71 & 44.49 & 32.49 & 38.35 & 33.37 & 37.51 & 39.84 & 37.33 \\
\hline $\begin{array}{l}\text { Somatic cells count } \\
\text { (n./mLx000) }\end{array}$ & 412 & 415 & 518 & 383 & 259 & 296 & 353 & 401 & 372 & 320 \\
\hline
\end{tabular}


Table 3S. Chemical composition (g/100 g, means \pm standard error; s.e.) of cheese from sheep reared on "pasture" (control group, CG) or on "pasture plus feed supplementation" (experimental group, EG).

\begin{tabular}{cccc}
\hline Analysis & July 8,2016 & \multicolumn{2}{c}{ August 9, 2016 } \\
\hline Items & CG & CG & EG \\
& $n=6$ & $n=6$ & $n=6$ \\
\hline Moisture & $30.76 \pm 0.72$ & $28.87 \pm 2.63$ & $26.49 \pm 1.32$ \\
Protein & $26.21 \pm 1.35$ & $25.68 \pm 0.55$ & $25.95 \pm 0.31$ \\
Fat & $37.87 \pm 1.13$ & $38.39 \pm 1.57$ & $40.44 \pm 0.91$ \\
Ash & $3.42 \pm 0.20$ & $3.50 \pm 0.04$ & $3.40 \pm 0.11$ \\
\hline
\end{tabular}


Table 4S. Minimum adequate models' parameters for log-transformed retinol and $\alpha$-tocopherol concentrations obtained after backward selection of variables (time, treatment and their interaction) of the respective maximal linear models. Slope estimates, $t$ and $p$ values at the cross between groups (experimental and control groups) and times (1 - July 08, 2016; 2 - July 13, 2016; 3 - July 21, 2016; 4 - July 27, 2016; 5 - August 09, 2016) refer to interaction terms (treatment : time).

\begin{tabular}{|c|c|c|c|c|c|c|c|c|c|c|c|c|}
\hline & \multirow[b]{2}{*}{ Time } & \multicolumn{3}{|c|}{ Experimental group } & \multicolumn{3}{|c|}{ Control group } & \multirow[b]{2}{*}{ Std. Error } & \multirow[b]{2}{*}{$\begin{array}{l}\text { Intercept } \\
\text { estimate }\end{array}$} & \multirow[b]{2}{*}{$A d j . R^{2}$} & \multirow[b]{2}{*}{$F$} & \multirow[b]{2}{*}{$p$} \\
\hline & & Slope estimate & $t$ & $p$ & $\begin{array}{c}\text { Slope } \\
\text { estimate }\end{array}$ & $t$ & $P$ & & & & & \\
\hline \multirow{5}{*}{ Retinol } & 1 & -0.3250 & -5.693 & $7.9010^{-8}$ & -0.3324 & -5.823 & $4.2910^{-8}$ & \multirow{5}{*}{0.0571} & \multirow{5}{*}{$0.0082^{\text {n.s. }}$} & \multirow{5}{*}{0.3855} & \multirow{5}{*}{10.69} & \multirow{5}{*}{$2.6710^{-12}$} \\
\hline & 2 & -0.0686 & -1.201 & 0.2318 & -0.3438 & -6.021 & $1.6610^{-8}$ & & & & & \\
\hline & 3 & -0.1094 & -1.917 & 0.0575 & -0.2907 & -5.092 & $1.2110^{-6}$ & & & & & \\
\hline & 4 & -0.0904 & -1.583 & 0.1157 & -0.2865 & -5.019 & $1.6710^{-6}$ & & & & & \\
\hline & 5 & NA & NA & NA & -0.3106 & -5.441 & $2.5410^{-7}$ & & & & & \\
\hline \multirow{5}{*}{$\alpha$-tocopherol } & 1 & -0.5791 & -7.581 & $5.7510^{-12}$ & -0.5817 & -7.615 & $4.8010^{-12}$ & \multirow{5}{*}{0.0764} & \multirow{5}{*}{$1.0767^{* * *}$} & \multirow{5}{*}{0.6063} & \multirow{5}{*}{24.78} & \multirow{5}{*}{$<2.210^{-16}$} \\
\hline & 2 & -0.0043 & -0.057 & 0.955 & -0.5652 & -7.398 & $1.5210^{-11}$ & & & & & \\
\hline & 3 & -0.0025 & -0.032 & 0.974 & -0.4295 & -5.622 & $1.1010^{-7}$ & & & & & \\
\hline & 4 & 0.0161 & 0.211 & 0.833 & -0.4486 & -5.872 & $3.3910^{-8}$ & & & & & \\
\hline & 5 & NA & NA & NA & -0.4363 & -5.711 & $7.2610^{-8}$ & & & & & \\
\hline
\end{tabular}

